Malin Pereira

\title{
An Angry, Mixed Race Cosmopolitanism: Race, Privilege, Poetic Identity, and Community in Natasha Trethewey's Beyond Katrina and Thrall
}

Pulitzer-Prize winner and former United States Poet Laureate Natasha Trethewey's fourth and fifth books, Beyond Katrina (2010) and Thrall (2012), depart from her first three books of poetry in several ways, most notably in the choice of genre and cultural materials. In Domestic Work (2000), Bellocq's Ophelia (2002), and Native Guard (2006), Trethewey's finely-wrought formalist poems explored materials from her African American maternal lineage in the South alongside historical and American frames shaping race, memory, and identity. Following these, as the poet Carolyn Hembree writes in her review, “Beyond Katrina marks Trethewey's departure from writing poetry exclusively to integrating various texts and styles in one book" (55), a mixed genre Trethewey terms a "meditation." Hembree finds this book "unfinished," citing the key example of Trethewey's mixed race, which she states "is not dealt with again" in the text after the poem "Kin" (56). Asking a number of questions about unresolved issues in the text, she concludes: "At the end of Beyond Katrina, the prodigal again returns from her ancestral home ... but what has she learned about herself?" (56). Trethewey's next book, Thrall, returns to the "deftly shaped" poetry for which she is known, but with a significant change in materials: She takes, as another review puts it, "her familiar powers to non-United States turf, considering ... paintings from Spain and Mexico” (Publisher's Weekly). These textual shifts, and reviewers' reactions to them, are related: The unfinished business of mixed race, identity, and community that surfaces through the genre of "meditation" in Beyond Katrina is returned to for working through in the cosmopolitan, ekphrastic poems of Thrall. Reading these two books as a pair explains why Trethewey shifts in Thrall to an international array of visual materials and employs what could be argued is a cosmopolitan mode, ekphrasis, to comment upon them; it also provides context for Trethewey's remark in an interview that the poet Ellen Voight felt there were more expressions of anger in her recent poetry after Native Guard, the roots of which become evident in Beyond Katrina. Together, these texts articulate a recognition and reversal narrative for Trethewey's mixed race poetic identity, one that presages a significant shift in her oeuvre. 


\section{Mixed Race and Poetic Identity}

Trethewey, the daughter of an African American Southern United States mother and a white rural Canadian father, has frequently probed her biraciality. Elsewhere, I have shown how a mixed race identity project forms an ongoing narrative through Trethewey's first three books of poetry, a narrative that complicates and readjusts previous scholarly readings of her work (Pereira, "Re-reading Trethewey through Mixed Race Studies”). This project continues in her fourth book. In Beyond Katrina, Trethewey strategically uses her personal stories of mixed race crossing as conduits into a systemic analysis of race and class in the United States. In a recent interview, she explains that "crossings and cross hatchings exist within my own blood. I think about Langston Hughes's poem 'Cross' concerning mixed race experience. And here I have lived and grown up in a place and a time where I could feel as if whatever story I had to tell could link what seemed to some people very disparate stories. That I myself embodied that sense of crossing" (Turner 6). She extends this idea to assert, "The story of America has always been a story of miscegenation, of border crossings, of integration of cultures, and again, I embody this in my person” (10). Trethewey's mixed race poetic identity thus acts as a constructed vehicle in the text through which she can identify and traverse race and class boundaries. In Beyond Katrina, Trethewey crosses between her comfortable New South lifestyle in Atlanta and her maternal African American family's hardships during and following Hurricane Katrina as it affected the Mississippi Gulf Coast; juxtaposing these two realities reveals and critiques boundaries of race and class reinforcing economic and social inequities in the United States. Importantly, Trethewey does not shy away from implicating herself in this interrogation; the self-critique that emerges in Beyond Katrina undergirds the angry cosmopolitanism that follows in Thrall.

Mixed race studies is a relatively new scholarly field in the United States, emerging in the 1990s with work by Paul Spikard, Maria Root, Naomi Zack, Werner Sollors, Linda Alcoff, and Jayne Ifekwunigwe, among others, as a response to perceptions of increasing numbers of biracial and multiracial people in the United States. One recent contribution to the field, Michele Elam's The Souls of Mixed Folk: Race, Politics, and Aesthetics in the New Millennium (2011), presents a significant and compelling challenge to early scholarship on mixed race. Looking specifically at black-white racial mixing, Elam critiques several key tenets of the mixed race movement in the United States, two of which are relevant here: the first, mixed race as "new" and an ideal, which she argues overlooks historical data on mixed race and glorifies the mixed race person as a savior who will repair our past and current racial problems; and the second, an emphasis on the individual, which she argues ignores history, power structures and social forces. Elam's analysis of a wide range of literature, comic strips and graphic novels demonstrates how the biracial works she studies are not invested 
in "imagining or narratively thematizing a vision of a better world or even necessarily a better way." Instead, Elam argues:

Their aesthetic style more frequently enacts the limitations on forms of expression or political sensibilities that might inhibit the imaginative realization of an alternative world, performing a formal meta-commentary on the problem of representing hard-to-solve and sometimes hardto-see social and racial inequities. This species of text, even when deploying humor, is not especially joyful nor uplifting. The works do not offer ... exemplary characters who model "the answer." (xvii)

One key contribution of Elam's work is the uncovering of class issues behind mixed race. As she reminds us, quoting Eva Saks, the anxieties surrounding miscegenation in the Southern United States were "more specifically an anxiety about establishing patriarchal lines of property, about the transmission of material goods within the white community, and the corresponding disinheritance of the black mother and any children born of an interracial union" (18). Today, Elam writes, "race and class continue to be indexed in close statistical relation; people of color who marry white or light tend to move upward in socioeconomic opportunity; mixed race children with one white parent tend then also to have a higher socioeconomic status, attend better schools, and live in better neighborhoods" (18).

The role that Trethewey's now-deceased father, a well-published poet and professor of English at Hollins University, played in her life evidences Elam's point that mixed race children with one white parent rise in socioeconomic opportunity. Mr. Trethewey served as a "literacy sponsor" (Deborah Brandt's term) for Ms. Trethewey's professional writerly identity. Interviews with Ms. Trethewey often invoke scenes of literary instruction by her father. He was one of her first creative writing teachers, as was his second wife, Katherine Soniat, a white US poet. Natasha Trethewey attended the university where they taught and, once she was a published poet, often gave poetry readings together with her father. Eric and Natasha Trethewey's masterapprentice relationship provided structural access for the younger Trethewey into the workings of academia and the publishing world. Her many successes-the Pulitzer Prize in Poetry, an endowed chair at Emory, two terms as United States Poet Laureate-can in some part be attributed to her access to and instruction in the power structure and systems governing poetry and academia. Her high degree of formal poetic literacy, and the success that comes with it, places her in a privileged position.

That privilege carries with it economic rewards, as this somewhat over-excited description of Trethewey's condominium in the suburb of Decatur, Georgia (just outside of Atlanta), by W. T. Pfefferle reveals: "Natasha buzzes me up, and I meet her and her husband. We stand in their glittering kitchen-not just spectacularly clean, but ringed with stainless steel appliances-and then Natasha and I go and sit on two overstuffed couches in the living room. ... She feels totally at ease in this pretty New South suburb” (163). 
From this position of "ease," Trethewey could in Beyond Katrina perform a narrative suggesting her success as a mixed race person illustrates how the United States has overcome racial and class biases and offering herself as a savior after Hurricane Katrina. Instead, Trethewey exposes her mixed race privilege in Beyond Katrina-the privilege to cross boundaries of race and class, the freedom to overlook hardships, the access to a degree of power and authority in the legal system, the privileging of "published poet" literacy over alternate genres and less credentialed literacies. Thus, as Elam demonstrates with other texts involving mixed race, Trethewey's Beyond Katrina performs "a formal meta-commentary on the problem of representing hardto-solve and sometimes hard-to-see social and racial inequities.” Trethewey presents in Beyond Katrina a persona whose mixed race privilege enables a series of meditative scenes of recognition and insight performing an ongoing critique of structural inequities in the United States.

\section{Race and Class Privilege-and (Not) Belonging-in Beyond Katrina}

One way that Trethewey identifies power and privilege at work is with the theme of competing narratives, as she describes in the first prose chapter, "Pilgrim": "This too is a story about a story. ... I wonder at the competing narratives: What will be remembered, what forgotten? What dominant narrative is now emerging?” (11). Returning home to Gulfport, Mississippi, to write about the disaster of Katrina for the Mississippi Gulf Coast, the figure Trethewey presents in the text as her self understands well the politics behind a writing project intended to tell the "story" of what happened to the Mississippi Gulf Coast because of Katrina. Citing public wrangling over differing versions of historical events- "the story that is to be told"-she identifies such contests as "rooted in power and money" to determine "how the past will be remembered, what narrative will be inscribed" (56). Evidencing the "doubled consciousness" of mixed race that Elam identifies, yet working to destabilize a narrative of the privileged as the "story," Trethewey moves the text across time, space, place, class, race, and gender. This fracturing of perspectives and stories functions as what Brent Hayes Edwards calls racial décalage, as "a time lag, gap or interval of time and space which articulates a difference across time and perspective” (13).

To access the competing narratives, Trethewey's persona interviews a range of figures crossing race, gender, age and class. Each narrative they share is carefully positioned in a perspective by Trethewey. The narrative moves the persona in and out of the perspectives of the people she interviews. Her doubled consciousness as mixed race facilities this movement. For example, walking through the lobby of the hotel she is staying at, she is "struck by the incongruousness of the high-end jewelry and clothing stores ... juxtaposed with what I know is just beyond the great entryway with 
its soaring great glass doors, giant flower arrangements, and extravagant perfume" (17-18). The financially comfortable Trethewey persona is able to stay in a high-end hotel while visiting Gulfport, yet she also claims-"what I know is just beyond the great entryway"-namely, other, less privileged perspectives, those of the working poor she has interviewed as well as those of her African American relatives, her brother, his girlfriend, and her maternal grandmother, whose experiences following Katrina demonstrate the structural inequities of race and class in the United States

The Trethewey figure presented in the text-importantly-is not a heroic figure who gives voice to or champions the perspective of those on the other side of the boundaries of race and class. In Beyond Katrina, the Trethewey persona's perspective never remains simplistically aligned with that of her relatives, as the poem "Kin" in the Part Two section titled "Congregation" demonstrates:

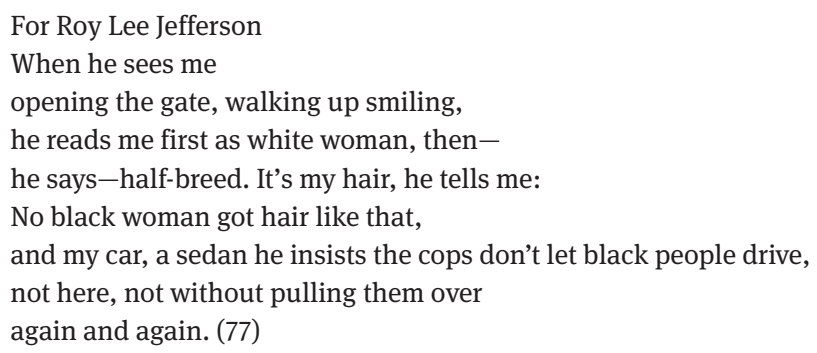

In these opening lines, Trethewey conveys the racial and class differences between her persona and the relatives she interviews. Even her kin read her appearance for racial markers, some of which are intertwined with markers of class status. She refuses to naively collapse such differences, maintaining the complexity of perspectives in a text in which all narratives are competing. Her privilege of mixed race is expressed not only in the fact that she can afford to drive a nice car, but also by the implication that, unlike her black kinfolk, she is not getting pulled over by the cops when she drives it there because she does not at first appear to be black. Seeing her through Roy Lee Jefferson's eyes, we achieve insight about the racial and class inequities of daily life in Gulfport, inequities that distance the Trethewey figure from her kin. That they experience inequity "again and again" and she does not underlines that these are not individual acts of racism, but endemic to the deep structures of the society. These inequities make her an outsider, even at home. Near the end of the poem, in a not very kin-like move, the relative calls her "White girl" and taunts her about coming out to his place in the country to see the baby he had with her cousin's sister-the reason they are "kin."

Trethewey highlights the persona's kin-at-a-remove status in order to refuse a naïve collapsing of race and class differences. Following "Kin," the poem "Prodigal" reflects further upon her insider-outsider status and delivers a moment of insight into her positionality. She writes: "I wanted to say I have come home / to bear witness. ... 
I wanted to say I see, / not I watch" (81). Trethewey as author had hoped she would not be an outsider to her family's and her hometown community's hardships, wanting to avoid touristic looking and see through the eyes of her people. She wanted her "seeing to be a sanctuary," but instead, she realizes one must "[f]ace the things that confront you" (81).

What confronts Trethewey in her text is realizing the privilege of her mixed race self. The final lines of the poem show her watching a service at her grandmother's neighborhood church from outside, her face pressed against the glass, until, she writes, "someone turned, looked back, saw me" (81). This moment of being seenoutside-springboards the text into its next section, beginning to turn the narrative toward her brother Joe's perspective, which dominates the final sections of the book. In telling his story and then letting him tell it through his letters to her from prison, Trethewey not only acknowledges the structural inequities in the United States undergirding her mixed race privilege, but also seeks to demonstrate and undo her own partial blindness to it. As she says in an interview with Christian Teresi, "I must understand my own complicity with acts of erasure" (50).

The contrast of Joe's circumstances and outcomes with her own that emerges in these sections brings the Trethewey persona to a self-recognition of the privilege and blindness stemming from being the daughter of a white poet father. Joe's story of his paternal and maternal inheritances, natural disaster, economic ruin, desperate choice, and prison run in contrasting parallel to his sister's. While Trethewey has inherited both race and class privilege from her white father, Joe's paternal inheritance is that his black father (Trethewey's stepfather) abused and then murdered their mother. While the natural disaster of Katrina affects them both, Trethewey is able to remain at a degree of remove, living in a suburb of Atlanta and teaching at Emory University, even relocating their grandmother there to care for her, whereas Joe has to grapple with the physical results of the hurricane as well as the impact of the disaster on his livelihood of managing properties he had inherited from the maternal side of the family. They had to be torn down, and he was held financially responsible for the expense of removal and also the tax bills for the land (a public policy that of course affects the economically vulnerable inequitably). He had no resources or employment options due to the impact of Katrina on the economy. So, at the same time that Trethewey wins the Pulitzer Prize for Poetry in 2007, her brother Joe is arrested for transporting cocaine for $\$ 4,000$, money he intended to use to pay the tax bills to keep the family land.

The competing narrative that emerges most strongly in Beyond Katrina is this story, Joe's story, acknowledged at the end by Trethewey as "the story all along” (127). In those 18 pages, Joe becomes the artist, the creator of the narrative. He even becomes the poet, writing the poem "Cycle" (included in the text) in which he rejects inheriting the identity of domestic abuser from his father. The reviewer Hembree critiques this element of the narrative, saying "his story should not eclipse hers" (56). But this precisely is where Trethewey addresses the mixed race privilege that begins to be 
revealed in "Kin.” Joe's story, as Trethewey positions it in the narrative to re-see that of her persona, expresses his disadvantages due to race and class and also unflinchingly reveals his sister's contrasting affluence, heightened credibility and power, and even writerly arrogance. The Trethewey figure in the last sections becomes a supportive yet nevertheless privileged and even complicit actor in her brother's difficult story. She serves as a character witness in court, testifying about her brother's disadvantages with heightened credibility (Joe's lawyer had told him she was needed to testify to keep him from going to prison for a very long time). She provides financial resources, agreeing to pay the tax bills on the land, and helping his girlfriend and their daughter. While these acts are what family do, that she is able to do them and has the power to be effective in her assistance marks her relative privilege. While Joe is jailed awaiting sentencing, Trethewey shows her persona beginning to understand her privilege and her complicity in maintaining elements of it. Trethewey writes about her phone calls to Joe, during which she was concerned about jailhouse safety for him:

I try to keep my voice steady when we talk, to hide that I am afraid. I keep thinking that this is best for his state of mind, but I know better. I am keeping a silence to protect myself from knowing. So often this is what silences-in families as well as in the public discourse of difficult events-are all about: if something isn't fully spoken, it isn't fully known, and we can absolve ourselves of the responsibility that knowing entails. (102)

Trethewey turns from revealing her individual silence to maintain the privilege of being unaware to naming larger societal silences that enable entire groups of people to remain unaware, in order to connect such individual acts to the continuing production of inequities often tied to race and class.

Staging her reading of his letters from prison as a series of insights, Trethewey brings her persona in the narrative to the realization of a key oversight: The author never wrote her brother a letter the entire time he was in prison. She talked with him frequently on the phone, she wired him spending money, she sent him care packages. But she never considered him a reader of her writing; she never considered writing for and to him. "It never occurred to me-and so I did not send-the one thing I know now he must have wanted more than anything: some words from me to hold on to longer than the ten minutes we were allowed to speak on the phone" (108). From this point on, the section is solely in Joe's voice, from his letters and the aforementioned poem he wrote while in prison. In so doing, Trethewey grants her brother the authorial privilege of controlling for a time the narrative she had assumed obtained only to herself.

Trethewey closes Beyond Katrina as Elam would have predicted, with a notuplifting final scene that critiques institutions and public policies that perpetuate differential access and privilege. In the final prose section following Joe's letters and poem, titled "Redux," Trethewey resumes narrative control to relate the day of her brother's sentencing. She writes that she recalls little else besides a teenage boy in 
a car asking her for directions to the public library while she was leaving the courthouse. She writes:

\begin{abstract}
He was riding with a woman who must have been his mother, and when she smiled at us, I could see that she was missing several of her front teeth. I remember too that the car had a Florida license plate-Escambia County-and that it was weighed down, the bumper nearly dragging the pavement. The back seat was loaded with what seemed to be all their possessions: I could see garbage bags spilling clothes, a couple of pillows and a comforter, the legs of an upended chair. ... I could imagine many reasons, beyond books, that they might need to reach the library: Internet access, an air-conditioned respite, a public restroom in a clean, comfortable building. (122)
\end{abstract}

Leaving the courthouse, having just watched her brother sentenced to prison, and asked directions to the public library, Trethewey draws a solid line connecting these two powerful public institutions and their failure to equitably meet the needs of all their citizens. Trethewey's persona is shown as able to see-and is positioned to help the reader empathetically see-this family's circumstances, which evoke those of her brother. Displaced by Katrina, and economically vulnerable even before that, the family's search for a public library complicates the library's role as providing access to books for fostering a literate citizenry. Beyond books-beyond Katrina-this family needs basic facilities to enable survival.

Raising her hand to point the way, the Trethewey figure stops when she realizes the library, destroyed by Katrina, hadn't been rebuilt (and, the author interjects, still has not been at the time of her writing). Her initial feeling of relief that she could provide help stalls. There is no answer. This scene of redux, this looking back in the narrative to the day of Joe's sentencing, thus looks back in order to name a lack of equal access to tools of bare survival, as well as to power and privilege. Symbolized here in the icon of the public library that has not yet been rebuilt, while the courthouse and high-end hotel are up and running (a failure of public policy to meet the needs of its most disadvantaged citizens), Trethewey recognizes and names larger structural inequities undergirding her and her brother's differing opportunities and outcomes. Trethewey's Beyond Katrina thus exposes "hard-to-see social and racial inequities"-even those that have been hard for her to see.

\title{
3 Un-homed, Anger, Community, the Personal
}

Trethewey depicts in Beyond Katrina her own distancing from her black maternal lineage and homeplace-a refuge created by black women for affirming one's humanity despite racism, as described by bell hooks in "Homeplace" (42)-key wellsprings of her poetic subject matter for her first three books of poetry. Her displacement from the role of insider within her black maternal community of the Mississippi Gulf Coast, as the narrator of the story, and even as poet, by her brother, Joe, is expressed in the 
work as a difficult journey that ultimately leaves her "un-homed" as a mixed race poet, paving the way toward a cosmopolitan stance. Susan Koshy notes, "[t]he feeling of not being at home is a marker of diasporic [cosmopolitan] citizenship” (601). The enormity of Trethewey's loss is clarified when one considers Elam's justification for excluding her in The Souls of Mixed Folk from her canon of mixed race artists. She writes: "I would not include Natasha Trethewey's collection of poetry, often dealing with miscegenation, Native Guard ... , in part because she situates her exploration so firmly within African American and American politics and traditions” (221). Trethewey's sense of being "firmly" situated ends with Native Guard. What follows in Beyond Katrina is what Christine C. Iijima Hall identifies as "the power differential of being White while also being a minority"; Iijima Hall further elaborates: “Guilt, sadness, confusion and anger may result from this power. For example, a [mixed race] White [and]-minority woman may be able to interact and move in networks that a monorace minority person cannot. She may feel a type of 'survivor guilt.' She may also have anger toward the racism that has brought about this dilemma” (242). This aptly describes how Trethewey depicts her self by the end of Beyond Katrina. Possessing more power and resources than her black half-brother, not able to speak from the position of or be seen by others as an insider in her former homeplace, feeling guilty about failing to write to her brother in prison, and-most especially-angry at both the institutional racism that perpetuates racial and economic disparities and her own privileges in relation to those disparities, the mixed race persona Trethewey presents at the end of her work is ripe for the kind of "killing rage" described by bell hooks which, when linked to a "passion for freedom and justice, ... illuminates, heals, and makes redemptive struggle possible" (Killing Rage 20). ${ }^{104}$ Anger is a new poetic stance for Trethewey, who is typically lauded for her poetic formal restraint. She commented on this shift in an interview with Alan Fox, revealing that the poet Ellen Voight said to her that she could hear anger emerging in her more recent poetry. Thrall thus can be seen as enacting Trethewey's angry post-Beyond Katrina critique of the racial discourse and privilege she inherited from her white paternal lineage.

This is not, I must emphasize, a tragic mulatta narrative. As Ifeoma Kiddoe Nwankwo's supple reading of Victor Séjour's short story “Le mulâtre” (1837) in Black Cosmopolitanism: Racial Consciousness and Transnational Identity in the NineteenthCentury Americas shows, rather than reading the story as "the self-hating/whitehating/confused/angry mulatto murders the white man who is the personification of his struggle with identity" (208), a “more nuanced reading” instead could emphasize factors of inequitable and oppressive treatment, violence, denial of one’s humanity, and limited, forced choice. As she explains:

104 Shanna Greene Benjamin's treatment of anger and Wanda Coleman in her Hecate essay, and our exchange about it as she wrote the essay, helped crystalize my thinking about anger. 
[R]eading [texts] through the search for equality enables us to grasp the unstated relationship to other people of African descent within a particular text.... [It also] allows us to acknowledge and engage differences between people of African descent while also speaking of and from the histories that connect them. It facilitates the recognition of variance and serves as an alternative to subsuming all people of African descent into the category "Black" in order to index the common horrific history that they share.... The implicit and explicit responses to dehumanization within a text becomes the focus. (208)

Viewed through this lens, Trethewey's anger in Thrall is not mulatto rage at or confusion about her mixed race identity. It is anger at the unequal treatment of blacks, the "slow violence" enacted upon them (Rob Nixon), ${ }^{105}$ the denial of their humanity and suffering, and the limited, forced choices provided them. In sum, as Nwankwo puts it, it is "the dehumanization fed by [a] racialist and racist framework that prompts violent action" (208). From this perspective, Trethewey in Thrall takes violent aim at the racialist and racist cosmopolitanism of the Enlightenment, reclaiming and elevating a black maternal legacy. She names and critiques the dehumanizing construction of mixed race internationally, articulating a shared history and constructing a community of shared mixed race experience.

The objectivity and large scale of this articulation might appear to leave out the personal story of the poet-persona. Yet Trethewey does not leave the personal story out at all. Many of the poems in Thrall rely upon identification of personal elements, such as "my father," and "I." This occurs in her earlier poetry as well, drawing as it does upon family members such as her aunt, grandmother, mother, and father. One of the difficulties for scholars of Trethewey is interpreting her work without falling into what the New Critics termed the "biographical fallacy." Scholar Pearl Amelia McHaney strongly warns against what she feels are biographical readings of Trethewey's work, asserting instead the importance of her larger national and cultural interrogations of "empire and white supremacy" (155). While that interrogation is a critical aspect of Trethewey's work, attending to Trethewey's use of personal material is also vitally important to understanding her approach to critique.106 Like Mary Prince in The History of Mary Prince, a West Indian Slave (1831), Trethewey in Thrall produces what Nwankwo terms a "community autoethnography"-a text created by the "othered"- "both to tell the

105 Nixon writes, "By slow violence, I mean a violence that occurs gradually and out of sight, a violence of delayed destruction that is dispersed across time and space, an attritional violence that is typically not viewed as violence at all. Violence is customarily conceived as an event of action that is immediate in time, explosive and spectacular in space, and as erupting into instant sensational visibility. We need, I believe, to engage a different kind of violence, a violence that is neither spectacular nor instantaneous, but rather incremental and accretive, its calamitous repercussions playing out across a range of temporal scales" (2). In Beyond Katrina, Trethewey unveils the slow violence of environmental predation of her former home, detailing the post-Hurricane Katrina devastation and inequitable rebuilding of the Mississippi Gulf Coast and its impact on her family.

106 A couple of wonderful conversations about McHaney's essay during the summer of 2016 with my student Thomas Simonson gave me food for thought as I processed why I disagree with her position. 
story of the community and to talk back to the dominant discourse on the group." A key feature of this text is that the story is told "both as an objective outsider providing information to an uninformed public and as an invested insider experiencing the treatment described" (167). The insider experience requires the personal story. Trethewey's entire oeuvre could in fact be described as community autoethnography, thereby justifying that we always include the personal story in our interpretations.

\section{Cosmopolitanism, Race, Poetic Identity, and Trethewey}

There are any number of definitions of cosmopolitanism I could draw upon here, such as Homi Bhabha’s “vernacular cosmopolitanism” or Kwame Anthony Appiah's "rooted cosmopolitanism." The two most useful, to me, in articulating a cosmopolitanism inclusive of racial identity are the "minority cosmopolitanism" of Susan Koshy, and the "Black cosmopolitanism” of Nwankwo. Koshy's definition details the "how" of cosmopolitan expression in literature quite deftly, so I will turn to that second, before several close readings of poems in Thrall. Nwankwo's version details the "why," which of course must come first, offering an important frame to name the relationships among cosmopolitanism, race, and poetic identity (or, as she terms, it, the Black subject). As she points out,

Cosmopolitanism, the definition of oneself through the world beyond one's own origins, was a crucial element of modernity (and the Enlightenment). Imperialism and Orientalism were in fact forms of European cosmopolitanism. ... It should come as no surprise, then, that responses and resistance to these totalizing and hegemonic cosmopolitanisms also often employ cosmopolitanism as a conceptual frame. (9)

Nwankwo's understanding of how black subjects responded to cosmopolitanism, and the options they had/have for responding, is useful for understanding the relationship between Trethewey's earlier works and her fifth book, Thrall. Nwankwo writes:

People of African descent's approaches to public self-representation were born, in significant part, of the Atlantic power structure's attempts to deny them access to cosmopolitan subjectivity. ... This denial ... coexisted with a denial of access for that same population to both national subjectivity and human subjectivity, and perhaps most significantly, with an emphasis (from above) on their race, effectively determining the possible parameters of identity for people of African descent. ... Race, nation, and humanity were the three major referents through which individuals defined themselves and others ... but only one of the three referents were allowed people of African descent-race. Consequently, this population essentially had to prioritize, and choose which of the parameters denied them they most wished to challenge, and by extension which referent they most wished to have the right to claim. (10) 
Trethewey's earlier works (as Elam noted), focus on claiming human and national (United States) identities for black and mixed race subjects, in the course of which the nation and humanity are reconceptualized through the eyes of black and mixed identities and thus re-imagined. With Thrall, Trethewey looks beyond the United States, accessing cosmopolitanism both to claim it and to critique it. She inhabits cosmopolitanism not as an enduring positionality, but more along the lines of Inderpal Grewal's notion that some subjects participate in cosmopolitanism "intermittently or in unstable ways" (38). To Nwankwo, cosmopolitanism is, borrowing from Audre Lorde, one of "the master's tools (Blackness being another) that people of African descent tested for its possible usefulness to at least get into the master's house, if not to destroy it” (11). So, from this perspective, Trethewey accesses cosmopolitanism as a tool to expose and critique the Enlightenment and its racialist/racist discourse. ${ }^{107}$

It is important to add here that Nwankwo does not posit a binary between blackness and cosmopolitanism. Instead, she argues, "Black cosmopolitanism is born of the interstices and intersections between two mutually constitutive cosmopolitanisms-a hegemonic cosmopolitanism, exemplified by the material and psychological violence of imperialism and slavery (including dehumanization), and a cosmopolitanism that is rooted in a common knowledge and memory of that violence" (13). This helps us see, again, why the personal matters in Trethewey's texts: In Thrall, Trethewey engages with two cosmopolitanisms, the one intertwined with Enlightenment "knowledge" that mixed race is a "stain" and a "lesser" humanity, justifying oppression and disenfranchisement (which she critiques), and the other, speaking the truth of mixed race experience and how it felt/feels, across cultures and peoples touched by European imperialism (with whom she connects as a found community).

Koshy's 2011 essay in PMLA, "Minority Cosmopolitanism," offers a theoretical frame and vocabulary to articulate how a text enacts these mutually constituted cosmopolitanisms. Like Nwankwo, Koshy refuses to see the minority as non-worldly, static, and uniform: "The frequent conflation of the minority with the subnational and the cosmopolitan with the global misconceives the complexity of both. It denies worldliness to the former and particularity to the latter. It misses their imbrications, past and present. It is inattentive to their production in networks and circuits that are irreducible to scale" (592). Koshy’s project, which conjoins the "historically divergent projects of ethnic studies and studies of cosmopolitanism" (592), coins the term "minority cosmopolitanism" to refer to "[t]ranslocal affiliations that are grounded in the experience of minority subjects and are marked by a critical awareness of the constraints of primary attachments such as family, religion, race, and nation and by an ethical or imaginative receptivity, orientation, or aspiration to an interconnected or shared world" (594). Koshy's formulation helps us see, again, how the personal

107 I make much the same point in my analysis of Wanda Coleman's "Retro Rogue Anthology" in Mercurochrome. 
elements of the story connect with a cosmopolitanism of shared experience. Minority cosmopolitanism breaks down traditional oppositions such as local/ethnic versus global/transnational by highlighting, according to Koshy, a "comparative cultural perspective"; this comparative cultural perspective, importantly, is enacted through both "centripetal and centrifugal energies-[a] centripetal capacity to intensify affiliations of race, ethnicity, and culture and [a] centrifugal capacity to extend these affiliations outward" (594). This expression of affiliations through energies works particularly well in close readings of poetry, as I will demonstrate shortly. It allows a kinetic cosmopolitanism, essential to the mutability of mixed race. While Nwankwo identifies a stance of critique toward cosmopolitanism, Koshy stresses how the subject experiences "a paradoxical relation to cross-cultural contact, registering the disruptions and asymmetries of intercultural encounter while sustaining an openness to its transformative possibilities" (594).

Through these frames, we can see how in Thrall Trethewey deploys a mixed race cosmopolitanism in which the poems move centripetally into personal, interracial family material and centrifugally into ekphrastic poems on art depicting interracial families and mixed race figures/artists. The poems show both critique of those depictions and the Enlightenment ideas behind them and expression of the feelings such experiences engendered in mixed race subjects, thereby creating a mixed race cosmopolitan community to supplement the Mississippi Gulf Coast community Trethewey can no longer truly go "home" to.

\section{Mixed Race Cosmopolitanism, Ekphrasis, Community, and the Black Mother in Thrall}

Trethewey's "killing rage” hooks has three intertwined targets in Thrall: one, anger at the discourse of racial mixing from the Enlightenment, expressed through a series of ekphrastic poems on paintings from Europe and the Americas depicting interracial families and mixed race persons, which reveal a hierarchical valuing of whiteness over blackness; two, anger at the white father (and, by extension, Thomas Jefferson, a founding father of the United States) as a purveyor of Enlightenment racial thought in his roles as father, husband/lover, and teacher/mentor; and three, anger at herself, for being in thrall to the white father and to his Enlightenment views, for being so much, as she writes, "her father's daughter," becoming a poet and eventually discovering how she has become un-homed from her black maternal lineage. Drawing upon this anger as a resource, Trethewey works as a poet in Thrall to metaphorically kill off the white father and Enlightenment "knowledge" about race and racial mixing, to re-situate the black mother as a beautiful, central, and even divine muse figure for the mixed race artist, and to connect a tangled and contradictory mixed race artistic identity to a mixed race cosmopolitan artistic discourse depicted in paintings, draw- 
ings and photographs by Spanish, Mexican, German, and US artists, thereby attaining a diasporic citizenship within a mixed race "home." Linked, as hooks suggests, to a passion for freedom and justice, the rage propelling the volume ultimately both illuminates and heals, albeit inconclusively.

The collection is structured centripetally and centrifugally, oscillating between material associated with local/personal mixed race experiences and international art depicting the same. Racial affiliation, a key feature of Koshy's framing of minority cosmopolitanism, is, however, highly conflicted: In poems drawing upon either personal or international material, or both, Trethewey depicts love and intimacy with whiteness and the father while also repeatedly rejecting, critiquing, and distancing from whiteness and the paternal; the collection also contains several poems that present speakers seeking, connecting with, and deifying the black maternal. That contradictory and complicated racial affiliation/rejection stages the imposed family drama of both the mixed race poet and, by extension, that of all peoples of mixed race experience under imperialism, which dehumanizes them and forces binaristic choices.

Thrall opens with an elegy for a father, written in a first-person voice typically associated with the poet, and beginning with an epigraph, "for my father." Such features invite us to connect the father to Trethewey's own father, Eric Trethewey, who, at the time of the collection's publication in 2012, was still living, thus suggesting this poem's role as a metaphoric killing of the father. The poet announces the complicated intimacy between the speaker and the father in the poem, both as father-daughter and as poets, through the metaphor of fishing. She writes of the father figure on a fishing trip with the speaker as child: "You kept casting / your line, and when it did not come back / empty, it was tangled with mine" (5). That the dedication of the collection is "To my Father," a shift from the "for my father" dedication of the poem itself and of Trethewey's first poetry collection, Domestic Work, signals that in Thrall, it is now the daughter-poet's turn to cast the lines, to be the "ruthless" one who writes the father's death elegy, symbolically ending his power.

Establishing that centripetal energy of love and affiliation yet rejection of the white father with the opening poem, the collection then moves centrifugally to connect to an international series of visual works depicting interracial families, whiteness and blackness, and mixed race people in relation to purported "knowledge" about them. In these ekphrastic, culturally comparative poems, Trethewey traces an Enlightenment-associated discourse of race in which: paternal whiteness is associated with power and knowledge; blackness in the mother, females, or children is depicted as dull and static, associated with inanimate objects, and devalued; and mixed race persons' value is calculated through proportion of white blood, expressed in a taxonomy of terms. Trethewey turns to paintings, drawings, and photographs because, as several scholars of mixed race studies have noted, racial categorization relies upon the visual to "see" supposed racial markers in order to read mixed race (Elam).

One key example, "Kitchen Maid with Supper at Emmaus, Or, the Mulata," illustrates how the volume Thrall moves mixed race affiliation centrifugally outward. 
Trethewey's sonnet reads the painting referenced, "Kitchen Maid with Supper at Emmaus," by Diego Velázquez (c. 1619) as a definition of the mixed race subject in Western racial ideology, repeating the subject/verb combination "she is" or "she's" five times. Solely associated with the objects of her work-all vessels waiting to be filled and used-the mulatta is described as a "stain," an "echo," a being who "listens," and who "leans." The poem highlights that she is not even the subject of the painting that depicts her: Instead, the focus is on Jesus, "framed in the scene behind her." In the final two lines, typically the epigrammatic turn in the sonnet, the imagery of white and light connect this definition of mixed race to the Enlightenment. Jesus is associated with whiteness and light, purity and insight; while the mulatta's white cap links her to him and these ideals, the link is only partial, as she is mixed race. Light falls on only half of her face, as half of the final sentence reads. The poem reveals how the painting constructs mixed race, suggesting that her partial blackness limits her range of knowledge to her place, the kitchen, and its objects.

Trethewey's poem critiques the Enlightenment's construction of Western racial ideology by viewing this 17 th century Spanish painting through her lens of mixed race affiliation: The poet adds the subtitle, "Or, the Mulata," to the title of the painting, thus shifting the emphasis and focus away from "Supper at Emmaus" and Jesus. This illustrates how minority cosmopolitan poets stand in what Koshy terms "paradoxical relation to cross-cultural contact, registering the disruptions and asymmetries of intercultural encounter while sustaining an openness to its transformative possibilities." The mixed race poet-speaker of this poem can only see the painting as asymmetrical to her worldview, limiting as it does the intellectual capacity of the mulatta kitchen maid. Therefore, the poet positions the reader to re-see the subject matter of the artwork through racially-affiliated eyes; such a re-positioning extends that affiliation centrifugally outward, creating transformative possibilities for the reader and the nation.

Trethewey links the works of visual art directly back to personal material in the final poem of the first section of Thrall, titled "Knowledge." Near the end, the poem turns from its third-person commentary on a chalk drawing of a group of white men depicted as seeking knowledge through dissection of a female body to a first-person speaker who connects the white men with Trethewey's father's dissection of her racially. Trethewey quotes from a poem by her father, titled "The Swing," in which he writes: "I study my crossbreed child" (30). She has spoken in multiple interviews about her concern with this line in his poem, which in her poem functions metaphorically as a "pen / poised above me, aimed straight for my heart." In the poem "Knowledge," Trethewey re-casts Eric Trethewey's line within the context of a larger cross-cultural discourse of race critiqued in her ekphrastic poems, thus bringing centripetally back to her local affiliation a minority cosmopolitan knowledge that provides correction and illumination of a false taxonomy of mixed race.

The trio of themes-love, knowledge, and forgiveness-suggested in the collection's two epigraphs, "What is love? One name for it is knowledge" by Robert Penn 
Warren and "After such knowledge, what forgiveness?" by T. S. Eliot, provide the narrative frame for the collection's grappling with mixed race: The complicated father-daughter love and rejection we saw expressed in the opening poem, "Elegy," is followed in the first section by both the purported "knowledge" about race in Enlightenment and its descendent in modern discourse as represented in the line from Eric Trethewey's poem, as well as the poet-speaker's knowledge of that "knowledge," its international context, and its falseness. The second section of Thrall then moves to work toward a partial forgiveness of the white father, a process in which the figure of the black mother becomes central. This section opens with a trio of poems titled "The Americans," on US historical depictions of blacks as inferior backdrops; the third poem in the series enacts a similar turn as in the first section from third-person to a first-person speaker and apparently personal childhood material. The poem, "Help, 1968," references a photograph by Robert Frank of a white infant in the arms of a black maid. Turning to first-person, Trethewey writes, "when my mother took me for walks, / she was mistaken again and again / for my maid" (35), thereby connecting the racist discourse of US culture centripetally to family and racial affiliation as well as centrifugally to the Enlightenment discourse on racial mixing exposed in the preceding section.

In the poems following, the speakers and occasions move repeatedly between personal and international material, fluidly drawing cross-cultural comparisons between the two and creating a mixed race community based on the experience. For example, the first-person poem "Mano Prieta," on the occasion of a family photograph in which the black mother's hand presses on the mixed race daughter's arm, leaving "the imprint / on my body of her lovely dark hand" is followed by "De Español y Negra; Mulata," on a painting by Miguel Cabrera in 1763, also depicting a family scene with a white father, black mother, and biracial daughter. In both ekphrastic poems, the white father is associated with power: In the first poem, he sits on a "throne"; in the second, his touch carries "dominion" and "possession." However, the position of the black mother shifts: Unlike the first poem, in which the mother is "perched on the edge" of the chair, in the second poem, the black mother literally moves to "the foreground," her blackness "advancing" and "spreading." In the final line, she has become "a great pendulum eclipsing the light" (40). In this transitional scene, the black mother moves to the forefront of the narrative, blocking out the Enlightenment discourse that positions her as inferior background.

Following this empowering affiliation with the black maternal figure, the remaining poems of section two reconsider the affiliation with/rejection of the white father. In two poetic sequences, "Mythology" and "Geography," the first-person speaker engages childhood scenes in which detachment from a now-diminished father and the past is featured. In "Mythology," the speaker refers to the past as "metaphor," a passage as "blocked," and "nostalgia" as "treachery"; ultimately, the speaker must, like Odysseus's "crew" upon encountering the Sirens, shut out "the sound of my father's voice" (41-43). The thrall of the father is difficult to resist. The following 
poem, "Geography," creates more distance between them, despite presenting three different connectors-road, river, and rails. In each case, the means that connect the speaker to the father and thus reflect love and intimacy are also the means of separation and distance: On the road the mother and child travel to meet the father, he feigns "hitchhiking" as if "a stranger / passing through to somewhere else" (45); on the river where they are enjoying a summer day, the father's sad songs propel the speaker to wade to the other side, where she looks back at him, "as if across the years: he's smaller, his voice / lost in the distance between us" (46); on the rails they walk along tracing memories, the father searches "for the railroad switch" that creates a separate path for the train (47). Speaking from a similarly detached affiliation, the speaker of the next poem, the ekphrastic "Torna Atrás," seeks simply "to understand / my father," asking how it isthat "a man could love-and so diminish what he loves" (49). In the final poems of this section, the speaker seems to forgive the father, seeing him as "fouled" and tangled in his own "chain[s]" (54) and also asks his forgiveness for her own shortcomings in the relationship (50-51). In the final poem of the section, "Rotation," the father figure is "turning to go, waning / like the moon" (55), no longer powerful or even present.

A key poem amidst the father figure poems in the second section, "Bird in the House," provides a counterpoint to the section's working through and letting go of the white father by connecting to Rita Dove who, as I have argued elsewhere, stands in for the black maternal in Trethewey's mixed race poetic genealogy (Pereira, Rita). "Bird in the House" alludes to Dove's poem, "In the Old Neighborhood," a poem about homecoming, identity, and cosmopolitanism. Prefacing this poem in the Introduction to her Selected Poems, Dove writes:

The mystery of destiny boils down to the ultimate-and ultimately unanswerable-questions: How does where I come from determine where I've ended up? Why am I what I am and not what I thought I would be? What did I think I would be? Where do I reside most completely? From time to time in my poetry I have tried to sidle up to the answers, to eavesdrop on the gods. My attempts often reach back to childhood, with its volatile pleasures and profound trepidations. (xxi)

Dove's poem about the old neighborhood, situated as a return to the speaker's childhood home in preparation for a sister's wedding, culminates in the accidental death of a bird in the attic fan of the house. As a figure for Dove herself-a poet who has several times punned on her last name in her poems-the bird expresses "what might have been" the fate of the poet, had she remained trapped in the attic, in the old neighborhood, "a bird with no song” (xxv), never able to connect with the cosmopolitan cities referenced in the newspaper the speaker is "snared" by as she reads, names like "Santiago, Paris, and Dakar" (xxiii).

In Trethewey's "Bird in the House," the dead bird becomes a figure for the speaker's deceased mother, for whom she still grieves. "Black as omen," the bird is "like a single crow / meaning sorrow" (50). Like Dove's poem, a wedding is involved-in Trethewey's poem, the father figure has remarried. To him, therefore, the cat has 
brought in a "gift," just one of several omens of joy that portend a happy future. To the speaker, however, the bird evokes unresolved grief over the loss of the black mother. The speaker awakens nightly from a dream, "my heart battering my rib cage- / a trapped, wild bird” (51). Trethewey's and Dove's poems both allude to Paul Laurence Dunbar's poem, "Sympathy," seen by many as an expression of the fate of the black poet. In Trethewey's poem, while the father figure deals with the dead bird, and thus the death of the speaker's black mother, by burying it in the backyard, "erasing it into the dirt," the speaker, instead, seeks to free her trapped heart, to excavate her love for the black mother, to resurrect her in some form as present, in order to be healed. That this poem is positioned amidst the father forgiveness poems in the second section suggests that such expression of love and affiliation with the black mother is central to her ability to forgive the white father.

Trethewey's bird figure and its connection to Rita Dove as a black poetic mother develops further in the first poem of the third section, the title poem "Thrall," the final ekphrastic poem in the collection, thus moving the local insights of the personal material in the previous section centrifugally to connect with global racial discourse on mixed race and family. This poem follows the career of a 17th-century Spanish mixed race slave who became an apprentice and then became a painter, Juan de Pareja, and comments on two paintings: first, one in which he was the subject for his master, Diego Velázquez, who was not his father but, as the speaker states, "he might have been"; and, second, another in which he painted himself into the scene. The parallel to Trethewey's apprenticeship to her father as a poet and one of her principal teachers is apparent. In the poem, the speaker Pareja moves from a slave who grinds the master's colors and hides his own artistic talent to a freed man yet still apprentice, who is repeatedly "fix[ed]" in his master's eye and painting. The apprentice comes to see himself through the eyes of the master: "For years I looked to it [the painting] as one looks into a mirror” (63). A year after Velázquez’s death, Pareja, however, paints himself as "a freeman in the House of Customs" (63). In his hand, Trethewey writes, is "an answer a slip of paper / my signature on it / Juan de Pareja 1661" (63). In this scene, the speaker positions himself as, finally, a freed artist, able to represent himself as he wishes. While he has been trained by the white father figure, it is the black maternal that serves as his muse and inspiration. The poem closes with this reflection by Pareja:

\author{
Now \\ At the bright end \\ of sleep mother \\ She comes back to me \\ as sound \\ her voice \\ in the echo of birdcall \\ a single syllable \\ again
}


and again my name

Juan Juan Juan

or a bit of song that

waking

I cannot grasp

In these lines, Trethewey recaptures the "birdcall" of the black maternal as a key emotional component for the mixed race artist, the root of the song, or artistic expression. In the poem following, titled "Calling," Trethewey presents the black maternal as deified. In a baptismal scene, the speaker is immersed in the pool, the mother's body "between me and the high sun, a corona of light / around her face" (67). The speaker demands, "Why not call it / a vision? What I know is this: / I was drowning and saw a dark Madonna; / someone pulled me through / the water's bright ceiling / and I rose, initiate, / from one life into another" (67). The poem's light imagery and title, "Calling," suggest that the mixed race poet is enlightened by the black mother and thereby called to their life's work through her. This elevation of the black maternal provides a counter-narrative to the oppressive, dehumanizing construction of race in Enlightenment discourse and to hegemonic cosmopolitanism, presenting an alternative enlightenment.

Despite this momentary enlightenment, Thrall as a collection of poems concludes inconclusively, with a series of six poems following the title poem, “Thrall," meditating on the futility of circling back to these cultural foundations and to the past, and ending with the failure of either words or blackness to vanquish the whiteness "hover[ing] beneath / silent, incendiary / waiting" (78). Trethewey operates under no illusion that her text has heroically overthrown hegemonic cosmopolitanism. It has, however, critiqued representations of mixed race within that racialist/racist discourse. It has articulated the lived and felt experience of mixed race peoples across various cultures and times, creating a sense of home and community. Furthermore, it has inscribed the importance and core humanity of the need for the black maternal in Trethewey's poetic lineage. Perhaps with these illuminations comes some healing for us all.

\section{Works Cited}

Appiah, Kwame Anthony. "Rooted Cosmopolitanism." The Ethics of Identity, Princeton UP, 2005, pp. 213-272.

Bennett, Regina, et. al. "Outside the Frame: An Interview with Poet Natasha Trethewey." Oklahoma Humanities, vol. 3, no. 2, 2010, pp. 25-29.

Bhabha, Homi. "The Vernacular Cosmopolitan." Voices of the Crossing: The Impact of Britain on Writers from Asia, the Caribbean, and Africa, edited by Ferdinand Dennis and Naseem Khan, Serpent's Tail, 2000, pp. 133-142.

Bingham, Remica L. “Interview with Natasha Trethewey.” Poemmemoirstory, vol. 8, 2008, pp. 1-20. 
Benjamin, Shanna Greene. "The Uses of Anger: Wanda Coleman and the Poetics of Black Rage." Hecate: Focus Section: Wanda Coleman, vol. 40, no. 1, 2014, pp. 58-79.

Brandt, Deborah. "Sponsors of Literacy." College Composition and Communication, vol. 49, no. 2, 1998, pp. 165-185.

Chang, Jennifer. "The Public Life of Poetry: An Interview with Natasha Trethewey." LA Review of Books, June 2013, lareviewofbooks.org/article.php?id=1751\&fulltext=1. Accessed 10 July 2013.

Davis, Thadious M. Southscapes: Geographies of Race, Region, \& Literature. U of North Carolina P, 2011.

Dove, Rita. Selected Poems. Vintage, 1993.

Dove, Rita, and Natasha Trethewey. "Emory University Creativity Conversations." Moderated by Rudolph Byrd, 22 Mar. 2011, creativity.emory.edu/documents/creativity-convotranscripts/2011/Dove_Tretheway_transcript.pdf. Accessed 10 July 2013. Transcript.

Edwards, Brent Hayes. The Practice of Diaspora: Literature, Translation, and the Rise of Black Internationalism. Harvard UP, 2003.

Elam, Michele. The Souls of Mixed Folk: Race, Politics, and Aesthetics in the New Millennium. Stanford UP, 2011.

Fox, Alan. "A Conversation with Natasha Trethewey." Rattle, vol. 14, no. 2, 2008, pp. 179-190.

Gilroy, Paul. The Black Atlantic: Modernity and Double Consciousness. Harvard UP, 1993.

Grewal, Inderpal. Transnational America: Feminisms, Diasporas, Neoliberalisms. Duke UP, 2005.

Haney, David. "A Conversation with Natasha Trethewey." Cold Mountain Review, vol. 33, no. 1, 2004, pp. 19-34.

Hembree, Carolyn. "Review of Beyond Katrina, by Natasha Trethewey.” Arkansas Review, vol. 43, no. 1, 2012, pp. 55-56.

hooks, bell. “Homeplace." Yearning: Race, Gender, and Cultural Politics, South End P, 2000, pp. 41-49.

---. Killing Rage: Ending Racism. Henry Holt \& Co, 1995.

Koshy, Susan. “Minority Cosmopolitanism.” PMLA, vol. 126, no. 3, May 2011, pp. 592-609.

McHaney, Pearl Amelia. “Natasha Trethewey's Triptych: The Bodies of History in Bellocq's Ophelia, Native Guard, and Thrall." The Southern Quarterly: A Journal of Arts \& Letters in the South, vol. 50, no. 4, Summer 2013, pp. 153-172.

Nixon, Rob. Slow Violence and the Environmentalism of the Poor. Harvard UP, 2013.

Nwankwo, Ifeoma Kiddoe. Black Cosmopolitanism: Racial Consciousness and Transnational Identity in the Nineteenth-Century Americas. U of Pennsylvania P, 2005.

Pereira, Malin. "Re-Reading Trethewey through Mixed Race Studies." The Southern Quarterly: A Journal of Arts \& Letters in the South, vol. 50 no. 4, Summer 2013, pp. 123-152.

-.-. Rita Dove's Cosmopolitanism. U of Illinois P, 2003.

--.. "Wanda Coleman's 'Retro Rogue Anthology' in Mercurochrome." Hecate: Focus Section: Wanda Coleman, vol. 40, no. 1, 2014, pp. 97-115.

Petty, Jill. “An Interview with Natasha Trethewey." Callaloo, vol. 19, no. 2, 1996, pp. 364-375.

Pfefferle, W. T. "Natasha Trethewey: Decatur, Georgia." Poets on Place: Tales and Interviews from the Road. Utah State UP, 2005, pp. 163-165.

Review of Thrall. Publisher's Weekly, Sept. 2012, www.publishersweekly.com/978-0-547-57160-7. Accessed 17 May 2013.

Rowell, Charles Henry. "Inscriptive Restorations: An Interview with Natasha Trethewey." Callaloo, vol. 27, no. 4, 2004, pp. 1021-1034.

Scott, Joan W. "Experience." Feminists Theorize the Political, edited by Judith Butler and Joan Wallach Scott, Routledge, 1992, p. 26.

Sollors, Werner. Neither Black nor White yet Both: Thematic Explorations of Interracial Literature. Oxford UP, 1997. 
Solomon, Deborah. “The Way We Live Now: Questions for Natasha Trethewey, Native Daughter.” The New York Times Magazine, 17 May 2007, p. 15.

Teresi, Christian. “An Interview with Natasha Trethewey.” Writer's Chronicle, vol. 44, no. 3, 2011, pp. 42-55.

Trethewey, Natasha D. Bellocq's Ophelia: Poems. Graywolf, 2002.

--.. Beyond Katrina: A Meditation on the Mississippi Gulf Coast. U of Georgia P, 2010.

--.. Domestic Work: Poems. Graywolf, 2000.

--.. Native Guard. Houghton Mifflin, 2007.

---. “Repentance.” Southern Quarterly, vol. 50, no. 1, Fall 2012, pp. 197-198.

---. Thrall: Poems. Houghton Mifflin Harcourt, 2000.

Turner, Daniel Cross. "Southern Crossings: An Interview with Natasha Trethewey." Waccamaw: A Journal of Contemporary Literature, no. 6, 2010, archived.waccamawjournal.com/pages. php?x=324. Accessed 9 Mar. 2018. 